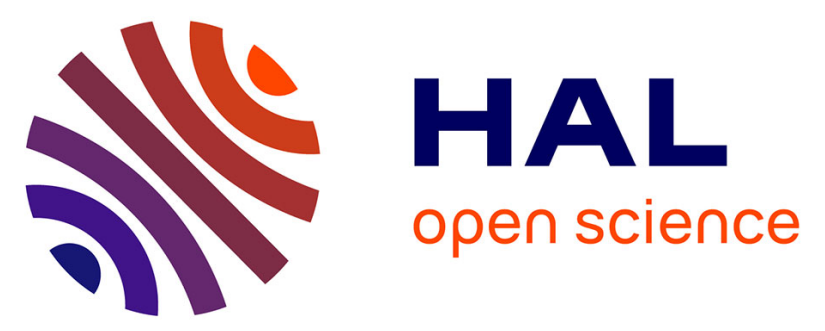

\title{
Effect of bioprocessing and fractionation on the structural, textural and sensory properties of gluten-free faba bean pasta
}

Natalia Rosa-Sibakov, Raija-Liisa Heiniö, Denis Cassan, Ulla

Holopainen-Mantila, Valerie Micard, Raija Lantto, Nesli Sozer

\section{To cite this version:}

Natalia Rosa-Sibakov, Raija-Liisa Heiniö, Denis Cassan, Ulla Holopainen-Mantila, Valerie Micard, et al.. Effect of bioprocessing and fractionation on the structural, textural and sensory properties of gluten-free faba bean pasta. LWT - Food Science and Technology, 2016, 67, pp.27-36. 10.1016/j.lwt.2015.11.032 . hal-01269388

\section{HAL Id: hal-01269388 \\ https://hal.science/hal-01269388}

Submitted on 27 May 2020

HAL is a multi-disciplinary open access archive for the deposit and dissemination of scientific research documents, whether they are published or not. The documents may come from teaching and research institutions in France or abroad, or from public or private research centers.
L'archive ouverte pluridisciplinaire HAL, est destinée au dépôt et à la diffusion de documents scientifiques de niveau recherche, publiés ou non, émanant des établissements d'enseignement et de recherche français ou étrangers, des laboratoires publics ou privés. 


\section{Accepted Manuscript}

Effect of bioprocessing and fractionation on the structural, textural and sensory properties of gluten-free faba bean pasta

Natalia Rosa-Sibakov, Raija-Liisa Heiniö, Denis Cassan, Ulla Holopainen-Mantila, Valérie Micard, Raija Lantto, Nesli Sozer

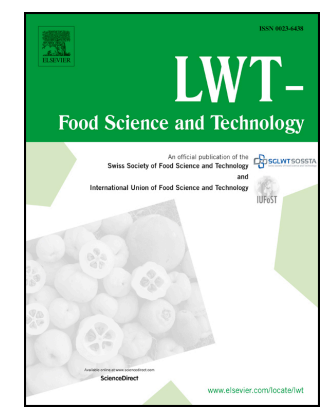

PII:

$$
\text { S0023-6438(15)30324-8 }
$$

DOI: 10.1016/j.Iwt.2015.11.032

Reference: $\quad$ YFSTL 5100

To appear in: $\quad$ LWT - Food Science and Technology

Received Date: 10 July 2015

Revised Date: 12 November 2015

Accepted Date: 17 November 2015

Please cite this article as: Rosa-Sibakov, N., Heiniö, R.-L., Cassan, D., Holopainen-Mantila, U., Micard, V., Lantto, R., Sozer, N., Effect of bioprocessing and fractionation on the structural, textural and sensory properties of gluten-free faba bean pasta, LWT - Food Science and Technology (2015), doi: 10.1016/ j.Iwt.2015.11.032.

This is a PDF file of an unedited manuscript that has been accepted for publication. As a service to our customers we are providing this early version of the manuscript. The manuscript will undergo copyediting, typesetting, and review of the resulting proof before it is published in its final form. Please note that during the production process errors may be discovered which could affect the content, and all legal disclaimers that apply to the journal pertain. 


\section{ACCEPTED MANUSCRIPT}

3

\section{faba bean pasta}

Natalia Rosa-Sibakov ${ }^{1 *}$, Raija-Liisa Heiniö ${ }^{1}$, Denis Cassan ${ }^{2}$, Ulla Holopainen-Mantila ${ }^{1}$, Valérie Micard ${ }^{2}$, Raija

Effect of bioprocessing and fractionation on the structural, textural and sensory properties of gluten-free

(1)

$$
\text { Lantto }^{1} \text { and Nesli Sozer }{ }^{1}
$$




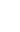

\section{Abstract}

This work evaluated the effects of processing faba bean flour on textural, structural and sensory properties of gluten-free pasta. Pasta was prepared using faba bean flour, starch-rich fraction of faba bean flour or faba bean flour fermented with lactic acid bacteria. The impact of cross-linking enzyme transglutaminase (TG) on the quality of faba pasta was also studied. The structure, cooking quality, starch digestibility, textural and sensory characteristics of faba pasta samples were evaluated and compared to semolina pasta. Pasta prepared with faba bean and fermented faba bean flours had higher cooking loss (10.8-11.5\%) and lower water absorption (130-160\%) than semolina pasta (6 and $193 \%$ ), but pasta prepared from fractionated faba flour had similar water absorption to semolina pasta. The texture of pasta made with faba bean flour was comparable to that of semolina pasta. Fermentation adversely affected the texture by increasing hardness, chewiness, sourness and flavour intensity. Starch hydrolysis index of pasta prepared with the three faba bean flours was similar to semolina pasta (46-50). TG reduced the in vitro starch hydrolysis index and increased some textural parameters of pasta made with faba bean flour, but no influence was observed on pasta made with fractionated or fermented faba. 


\section{Introduction}

Pulses such as peas, chickpeas and faba beans are good sources of proteins, dietary fibre and bioactive compounds. There is evidence that the consumption of pulses is linked to many health benefits, including reduced risk of diabetes, cardiovascular disease and certain cancers (Campos-Vega, Loarca-Piña, \& Oomah, 2010). Pulses have high protein content $(20-36 \%)$ that is about twice of the content of cereals, making pulses a good substitute for meat and a potential protein-rich ingredient. Faba bean is rich in favourable proteins (about $30 \%$ of lysine-rich proteins), vitamins, minerals and dietary fibre but also bioactive compounds, such as phenols and $\gamma$-aminobutyric acid (Jezierny, Mosenthin, \& Bauer, 2010). Currently faba bean is mainly used for feed. During the past decades there have been a few studies where faba bean was used for fortification of protein content in food products such as bread, biscuit and pasta (Abdel-Kader, 2000; Giménez, Drago, De Greef, Gonzalez, Lobo, \& Samman, 2012; Petitot, Barron, Morel, \& Micard, 2010a; Rababah et al., 2006).

One of the main limiting factors for using faba bean in food is its anti-nutritional compounds, such as condensed tannins and pyrimidine glycosides called vicine and convicine (Jamalian, 1999). In order to reduce the content of anti-nutritional factors, several methods have been applied in faba beans such as dehulling, soaking, cooking, microwave and autoclaving (Luo \& Xie, 2013). Recently, the potential of air classification and lactic acid bacteria fermentation to produce valuable faba bean ingredients has been reported (Coda et al., 2015). Fermentation decreased anti-nutritional compounds, increased the amount of free essential amino acids, improved the in vitro protein digestibility and lowered the starch hydrolysis index (Coda et al., 2015). Air classification was successfully applied to faba bean flour for efficient separation of protein and starch rich fractions (Gunawardena, Zijlstra, \& Beltranena, 2010). Moreover, starch rich fraction presented lower amount of anti-nutritional compounds, such as vicine, convicine, phytic acid and condensed tannins (Coda et al., 2015).

Besides its excellent nutritional profile, faba bean is gluten-free and could thus be utilized for both gluten sensitive and celiac patients. In the manufacture of gluten-free pasta, faba bean has been used for 
fortification (10 - 30\% w/w) of gluten-free flours (corn and amaranthus) (Chillo, Laverse, Falcone, \& Del Nobile, 2008; Giménez, González, Wagner, Torres, Lobo, \& Samman, 2013). Pasta prepared only from nongluten flours is generally considered to have an inferior quality than semolina pasta due to the lack of gluten functionality, which is responsible for structure formation, elasticity and al dente texture. Some suggested strategies to mimic gluten network in pasta are use of crosslinking enzymes, additives and texturing agents (hydrocolloids and emulsifiers) as well as pre-gelatinization of starch (Marti \& Pagani, 2013). Transglutaminase (TG: glutaminylpeptide:amine $\gamma$-glutamyltransferase) catalyzes an acyl transfer reaction between the $\psi$-carboxyamide group of a protein-bound glutamine residue and a primary amine or the amino group of a protein-bound lysine side chain to form covalent cross-links of $\varepsilon$ - $(\gamma$-Gln)-Lys bonds (Folk \& Finlayson, 1977). The intermolecular crosslinks introduced by TG change the protein structure and could improve the textural properties of gluten-free pasta by entrapping starch in the protein network induced by TG. The effect of TG has been studied only for gluten-free noodles (rice or corn) (Kim, Kee, Lee, \& Yoo, 2014; Yalcin \& Basman, 2008).

The objective of this work was to evaluate the effects of processed faba bean flour on the mechanical, structural and sensory properties of gluten-free pasta. Faba bean flour was either fractionated by air classification or fermented by lactic acid bacteria. The faba bean fractions obtained were used as the sole ingredient for manufacturing gluten-free pasta. Due to the lack of gluten network, a cross-linking enzyme transglutaminase was also added to the faba bean fractions in order to evaluate its effect on the structure and texture of gluten-free faba bean pasta. To the best of our knowledge, this is the first study reporting the use of faba bean ingredients as the sole ingredient for gluten-free pasta.

\section{Material and Methods}


Faba beans (cv. Kontu, cultivated in Finland in 2011, provided by University of Helsinki, Department of Agricultural Sciences) were stone milled, dehulled and ground into flour (Faba) for further air classification or fermentation as described in Coda et al. (2015). For air classification, ground faba bean flour was separated into protein and starch rich fractions (Starch-Faba). Fermentation of ground faba bean flour (Ferm-Faba) was carried out with the selected lactic acid bacteria $\left(30^{\circ} \mathrm{C}, 48 \mathrm{~h}\right)$ mixed with water in a ratio of 50:50 (wt:vol) and then freeze dried and milled (Coda et al., 2015). Three materials were used in this study for manufacturing pasta: faba bean flour (Faba), starch-rich fraction (Starch-Faba) and fermented faba bean flour (Ferm-Faba). The mean particle size $\left(D_{50}\right)$ of Faba, Starch-Faba and Ferm-Faba flours was $17.6 \pm 1,23.8$ \pm 0.2 and $63.7 \pm 2.8 \mu \mathrm{m}$, respectively (Coda et al., 2015). The chemical composition of raw materials was reported in Coda et al. (2015)

\subsection{Pasta production}

All pasta samples were manufactured in the National Technological Platform of JRU IATE (Montpellier, France) on a lab-scale pasta discontinuous extruder (Sercom, Montpellier, France) according to Petitot, Boyer, Minier, \& Micard (2010b). Durum wheat semolina was hydrated with distilled water to $470 \mathrm{~g} / \mathrm{kg}$ (db) moisture content and mixed for $5 \mathrm{~min}$ at $120 \mathrm{rpm}$ then $15 \mathrm{~min}$ at $60 \mathrm{rpm}$. The product was extruded (20 $\mathrm{rpm}, 40^{\circ} \mathrm{C}$ ) and dried $\left(55^{\circ} \mathrm{C}\right)$ in a pilot- scale drier (AFREM, Lyon, France). During the drying, the relative humidity gradually reduced from 88 to $70 \% \mathrm{RH}$ for 15 hours in order to reach $12 \%$ of moisture in the final product. The three faba bean materials (Faba, Starch-Faba and Ferm-Faba) were processed as described for semolina with some modifications. Hydration was reduced to 400,380 and $310 \mathrm{~g} / \mathrm{kg}(\mathrm{db})$, respectively, mixing time was reduced to $10 \mathrm{~min}$ and mixing speed increased to $120 \mathrm{rpm}$. The hydration level was modified based on preliminary evaluation of hydration properties of the flours in a farinograph (Petitot et al., 2010b) and the mixing speed was increased to $120 \mathrm{rpm}$ for pasta made with faba bean flours in order to limit the formation of particle aggregates. Transglutaminase (TG) enzyme Activa WM (Ajinomoto, MesnilSaint-Nicaise, France) was also added in faba flours for preparing pasta. In this case, the enzyme powder 
was mixed to the faba flours (20 nkat/g flour $\mathrm{dm}$ ) during $10 \mathrm{~min}(120 \mathrm{rpm})$ before the hydration step. The pasta samples with TG were named as Faba-TG, Starch-Faba-TG and Ferm-Faba-TG and produced as described above for faba bean flours without TG. The dosage of TG was chosen based on preliminary screening trials with faba bean flour and evaluated by the intensity of protein crosslinking on SDS-page (data not shown).

\subsection{Chemical characterization}

Moisture and total protein concentration were analysed according to the methods $44-15.02$ (AACCInternational, 2013) and 46-11A (AACC, 2003), respectively. Total and resistant starches were analysed using Megazyme kits (K-TSTA 09/14 and K-RSTAR 09/14) according to the AACC methods 76-13.01 and 3240.01, respectively. Ash content was determined with gravimetric method using Naber N11 ash oven (Nabertherm, Lilienthal, Germany). Fat was determined using Soxhlet extractor Büchi B-811 (Labortechnik AG, Flawil, Switzerland). Total dietary fibre was analysed with the enzymatic-gravimetric method 985.29 (AOAC, 1990). Chemical composition was performed in uncooked pasta. Protein and starches analysis were also performed in pasta samples after cooking.

2.4. Colour

Colour of dry spaghetti was determined by a Minolta Chroma Meter CR-200 (Konica Minolta Inc., Tokyo, Japan) using the Hunter $L^{*}, a^{*}, b^{*}$. Three measurements were taken for each replicate $(n=9)$.

\footnotetext{
Optimal cooking time (OCT): Dried spaghetti $(10 \mathrm{~cm}$ long) was cooked in distilled water $(10 \mathrm{~g} / 250 \mathrm{ml})$ and
} OCT was indicated when the white core of the pasta disappeared when squeezed between two glass plates. 
140 Cooking loss: Cooking loss was determined by weighing the residue (cooking water) after drying in an oven 141 at $105^{\circ} \mathrm{C}$ for 2 hours (Sozer, Dalgiç, \& Kaya, 2007).

Water absorption: Cooked samples were weighed soon after removing the excess water and dried in an oven at $105^{\circ} \mathrm{C}$ for 2 hours (Sozer et al., 2007).

\subsection{Starch hydrolysis index}

Pasta samples were cooked until their OCT, rinsed and minced (Kenwood, Havant, United Kingdom). In vitro starch digestibility was performed as described by Germaine, Samman, Fryirs, Griffiths, Johnson, and Quail (2008). Portions of the minced pasta containing $1 \mathrm{~g}$ of starch were weighted in $0.05 \mathrm{~mol} / \mathrm{L}$ sodium potassium phosphate buffer $(\mathrm{pH} 6.9)$, placed in water bath $\left(37^{\circ} \mathrm{C}\right)$ and pancreatic amylase $(110 \mathrm{U})$ was added to the suspensions. Sample aliquots were removed (time $=0,30,60,120$ and $180 \mathrm{~min}$ ), placed in boiling water bath, cooled in ice water and analysed for reducing sugar content. The area under the curve (AUC) and the hydrolysis index (HI) were calculated for each sample replicate using the equation:

$$
\mathrm{HI}=(\text { AUC pasta/average AUC white bread) } \times 100
$$

The average AUC of white bread tested using the equivalent method was given a value $\mathrm{HI}=100$.

The predicted glycemic (GI) indices of samples were calculated from HI values according to Granfeldt, Bjorck, Drews \& Tovar (1992) as Gl= $0.862 \mathrm{HI}+8.198$.

\subsection{Texture analysis}

Instrumental Texture Profile Analysis (TPA) was carried out with a Texture Analyzer TA.XT plus (Stable Micro Systems, Surrey, United Kingdom) containing a $294 \mathrm{~N}$ load cell and equipped with a pasta stickiness rig. Pasta samples were cooked, rinsed and analyzed immediately after cooking. Four spaghetti strands were placed adjacent to one another centrally under the compression platen of pasta firmness/stickiness 
rig (TA-HDP/PFS probe). Cooked spaghetti samples were compressed with a pre-test, test and post-test speed of $1 \mathrm{~mm} / \mathrm{s}$ to $70 \%$ of the initial spaghetti thickness. Measurements were performed five times with two independent experiments $(n=10)$. The test is a simulation of the action of jaw by compressing the bite size of food two times. Exponent software version 6.0.7.0 (Stable Micro Systems, Surrey, United Kingdom) was used to obtain values for the calculation of primary parameters (hardness, cohesiveness, springiness and adhesiveness) and secondary parameters (chewiness and resilience).

\subsection{Microscopy}

\subsubsection{Stereomicroscopy}

Samples were examined with Zeiss SteREO Discovery.V8 stereomicroscope equipped with Achromat S $0.5 x$ objective (Carl Zeiss Microlmaging $\mathrm{GmbH}$, Göttingen, Germany) and imaged using an Olympus DP-25 single chip colour CCD camera (Olympus Life Science Europa GmbH, Hamburg, Germany) and the Cell^P imaging software (Olympus). The diameter of uncooked, hydrated (in glutaraldehyde) and cooked pasta was also measured by images taken with the stereomicroscope. The results were calculated as average of 4 replicate measurements from 12 replicate piece of pasta (48 values in total).

\subsubsection{Light microscopy}

Pasta samples were prepared for microscopy as described by Curiel et al. 2014 except for uncooked pasta samples which were hydrated with $5 \mathrm{~g} / \mathrm{kg}$ glutaraldehyde for 30 min before embedding into agar. Sections from polymerized sample blocks were cut in a rotary microtome HM 355S (Microm Laborgeräte $\mathrm{GmbH}$, Walldorf, Germany) using a tungsten carbon knife. Staining of protein and starch in $2 \mu \mathrm{m}$ thick sections with Light Green and Lugol's iodine, respectively, was carried out according to Coda et al. 2015. 


\subsection{Sensory characteristics}

Sensory evaluation of cooked pasta was carried out at the sensory laboratory of VTT, which fulfils the requirements of the ISO standards (ISO 2005 and 2007). The sensory panel consisted of 10 trained assessors. The method in sensory profiling was descriptive analysis (Lawless \& Heymann, 2010). The attributes evaluated were yellowness of colour (visual evaluation on scale from yellow to red), elasticity (pulling with fingers), hardness (evaluation in mouth), chewiness (chewing with molar teeth), stickiness (evaluation of stickiness in teeth by tongue), sourness (while chewing), flavour intensity (while chewing) and intensity of possible off-flavour (while chewing). The attribute intensities $(0-10)$ were rated on continuous graphical intensity scales (10 cm in length). The samples were judged in two replicate sessions. The scores were recorded and collected using a computerized Compusense Five data system (Compusense, Guelph, Canada).

\subsection{Statistical data analysis}

Data were subjected to analysis of variance using IBM SPSS Statistics 21 (IBM Corporation, New York, USA), and significant differences $(p<0.05)$ between individual means were identified by Tukey's test. Correlation coefficients $(r)$ were analysed by Person's correlation with a $95 \%$ confidence. The intensities of the perceived texture attributes of the sensory profiles and levels of the instrumental structure attributes of pasta were related statistically by PLS (partial least squares) regression using an Unscrambler software package. Both the sensory and instrumental data were standardized and instrumental data also normalized before the multivariate analysis by Unscrambler. The model was validated by cross-validation. PLS regression is specifically designed to determine relationships existing between blocks of dependent $(\mathrm{Y}$ sensory) and independent ( $\mathrm{X}$ instrumental) variables by seeking underlying factors common to both sets of variables. 


\section{Results \& Discussion}

\subsection{Chemical characteristics of pasta}

The two main components of faba bean pasta were protein and starch (Table 1). Faba and Ferm-Faba pasta had 2.5-fold higher protein content $(350 \mathrm{~g} / \mathrm{kg})$ than regular durum wheat semolina pasta $(140 \mathrm{~g} / \mathrm{kg})$.

The protein content of faba bean pasta in the present study was 1.8-times more than the maximum protein content achieved with faba bean flour enriched pasta reported in Petitot et al., 2010b. Fermentation did not impact on the total amount of total fibre and air classification only slight reduced it. Faba, Starch-Faba and Ferm-Faba pasta had 1.5, 1.8 and $1.1 \mathrm{~g}$ resistant starch/100 g dry pasta, respectively which was almost three times higher than the semolina pasta ( $0.5 \mathrm{~g} \mathrm{RS} / 100 \mathrm{~g}$ dry pasta). Pulses in general have high content of resistant starch (Guillon \& Champ, 2002). In processed foods proteins may encapsulate the starch granules (Tovar, Bjork, \& Asp, 1990). Addition of TG increased the amount of resistant starch in Faba-TG pasta and Starch-Faba-TG, but not in Ferm-Faba-TG (Table 1). Fermented faba bean had its protein hydrolysed and a high amount of free lysine was released (Coda et al., 2015). Since TG catalyses the reaction between the amino group of a protein-bound glutamine residue with lysine, TG probably could not make covalent crosslinks between protein chains in fermented faba pasta but rather make the covalent bond between protein bound glutamine and free lysine. In Faba-TG and Starch-Faba-TG, TG probably enveloped starch in within a protein network structure resistant to digestion. Kuraishi, Yamazaki, and Susa with TG. 
The cross-section of uncooked spaghetti pasta (Fig. 1A-1D) illustrated the structure of faba and 234 semolina samples and also the differences in protein content of faba samples. The cross-section of 235 uncooked Faba and Starch-Faba had similar appearance, but Ferm-Faba seemed to have more 236 homogeneous structure and its edge had a perfect delineation. The matrix of starch granules and protein in uncooked samples are shown in Fig. 1A-1D with higher magnification. In semolina pasta, the size distribution ( $A, B$ and $C$ classes from largest to smallest ones) and shapes typical to cereal starch granules were observed. Large starch granules were lenticular and the smaller ones more spherical. Starch granules of faba bean were more rounded and they were more homogeneous in size compared to cereal starch as in Petitot et al. (2010a). According to high protein content of three faba bean pasta samples, the starch granules in these samples were shown to be embedded in denser protein matrix compared to that reported by Petitot et al. (2010a) for pasta containing both faba bean and semolina flour and having lower protein content.

Microscopic pictures were taken on the edges of cooked pasta samples (Fig. 1E-1K). In semolina pasta, protein network envelops starch and protects its leakage out from the outer surface during cooking (Fig. 1H). However, the outermost layers of faba bean pasta samples were lacking the starch granules (Fig. 1E-1G and $1 \mathrm{I}-\mathrm{K})$. The disruption of edges was less pronounced in the Ferm-Faba-TG sample. This explains the higher cooking loss of faba bean pasta samples compared to semolina pasta. In all the samples, amylose leached from the granules to the aqueous phase (stained in dark blue) and amylopectin (stained in brown) appeared inside of the granule, characteristics of complete starch gelatinization process in the outermost parts of the spaghetti (Fig. 1E-K). In both fermented pasta samples (Ferm-Faba and Ferm-Faba-TG), individual starch granules were regularly surrounded by protein, but in other faba bean pasta samples starch granules formed aggregates. Thus, protein matrix in Ferm-Faba seemed more continuous than in Faba or Starch-Faba pasta independently of TG.

Differences in the swelling of faba bean starch were noticed in the images taken from the halfway of the spaghetti radius (Fig. 2). Faba (Fig. 2A) and Starch-Faba (Fig. 2C) pasta had the most swollen starch 
granules and the starch in the corresponding samples with TG (Fig. 2B and 2D) was less swollen. In FermFaba (Fig. 2E) and Ferm-Faba-TG (Fig. 2F) the starch was least swollen and no differences in starch swelling were observed between them. It could be speculated that TG had an effect of forming a stronger protein network in Faba-TG and Starch-Faba-TG pasta which avoided the swollen of their starch granules. Sissons, Aravind, and Fellows (2010) also observed a more cohesive and thicker protein network in the microscopic pictures of semolina pasta with TG, which was concomitant with the increase on the formation of insoluble proteins (Sissons et al., 2010; Aalami \& Leelavathi, 2008).

\subsection{Cooking quality, swelling and colour characteristics}

Pasta produced with faba bean flours had lower OCT compared to semolina pasta (Table 2). The lowest OCT was observed for Ferm-Faba ( $6 \mathrm{~min})$, followed by Faba $(6.5 \mathrm{~min}$ ) and Starch-Faba ( $9 \mathrm{~min})$ pasta. OCT of pasta samples was positively correlated with their starch content $(r=0.97, \mathrm{p}<0.01)$, which means that more time was needed to gelatinise a higher amount of starch. The reduction in cooking time was accompanied by significantly lower water uptake for Ferm-Faba pasta (132\%) and Faba pasta (162\%) compared to semolina pasta (193\%). Starch-Faba pasta was the only sample with water absorption (195\%) statistically similar to semolina pasta. Water absorption of pasta samples was negatively correlated with the protein content of samples $(r=-0.81, \mathrm{p}<0.05)$ and positively correlated with the starch content of samples $(r=0.80$, p < 0.05). Doxastakis et al. (2007) and Petitot et al. (2010b) also observed a decrease in water absorption when spaghetti was enriched with lupine protein isolate and faba bean flour, respectively. Besides the amount of starch in faba bean pasta samples, their lower cooking time and lower water absorption could be related to the higher swelling of their starch granules (Fig. 2). This means that water could penetrate more easily in faba bean pasta samples allowing a faster starch gelatinization, which reduced the OCT and, consequently, water absorption during cooking.

Cooking loss of pasta prepared with faba bean flours was higher than semolina pasta (Table 2). No significant difference was observed between Faba, Ferm-Faba and Starch-Faba pasta related to cooking 
loss. No effect of TG addition was observed on cooking loss of Faba-TG or Starch-Faba-TG compared to

their respective pasta samples without TG, in agreement with Sissons et al. (2010). Addition of TG on

fermented faba flour slightly but significantly reduced the cooking loss. The fact that TG affected the cooking loss only for fermented faba remains unclear. The lower cooking quality of pasta prepared with faba bean flours was expected due to the lack of gluten, which is the responsible for the formation of the protein network structure holding starch. Enrichment of pasta with faba bean was previously reported to decrease cooking time, decreased water absorption and increased cooking loss when compared to semolina (Chillo et al., 2008; Giménez et al. 2012; Petitot et al. 2010b). In the case of gluten free pasta made with amaranth, faba bean and carboxymethylcellulose, the cooking loss was also high (11.4\%) (Chillo et al., 2008) reaching similar level of faba pasta samples. Giménez et al. (2013) enriched corn pasta with faba bean ( $30 \%$ of faba bean) and a cooking loss of $12.5 \%$ was reported. Similar cooking loss level was also observed in gluten free pasta made of rice (15.9\%) even though these samples had lower protein content are mainly globulins and albumins, which do not form an elastic network as the gliadins and glutenins of durum wheat. When the protein network lacks elasticity or its formation is delayed, starch granules will easily swell, and part of the starchy material will pass into the cooking water (Marti \& Pagani, 2013). This observation was confirmed when looking at microscopic pictures, which showed that starch granules of faba pasta are more swollen than in semolina pasta. The composition analyses performed on the cooked faba pasta samples (data not shown) showed that the proportion of protein and starch after cooking remained similar to the uncooked pasta. This means that faba pasta samples have lost similar amounts of components and not only starch or protein. diameter of pasta after hydration in glutaraldehyde was also measured (Table 2). Hydrated semolina pasta presented the lowest diameter $(1.85 \mathrm{~mm}$, compared to 2-2.1 $\mathrm{mm}$ for Faba, Starch-Faba and Ferm-Faba pastas), indicating more swelling of faba pasta samples. Water absorption rate of faba bean pasta samples 
allowing easy water penetration through starch granules. After cooking, the diameter of Starch-Faba pasta was similar to semolina pasta, but Faba had bigger diameter than semolina pasta. Ferm-Faba pasta had the smallest diameter (Table 2). Addition of TG had an influence on the diameter of Faba-TG and Starch-FabaTG, which were smaller than their correspondent pasta without TG.

Faba pasta had lower brightness and yellow colour values (around $10 \%$ lower) as well as more intense red colour than semolina (Table 2). These differences in colour parameters are likely due to the higher amount of ash and presence of outer layers on faba pasta samples. Ferm-Faba had the lowest brightness and yellowish values and the highest red value (Table 2). Fermentation of faba bean increased the amount of free amino acids (Coda et al., 2015), which probably triggered Maillard reactions during drying increasing the redness colour. Addition of transglutaminase on faba bean (Faba-TG) decreased the values of $\mathrm{L}^{*}$, $\mathrm{a}^{*}$ and $b^{*}$, although these differences were not visually detectable. Aalami \& Leelavathi (2008) also reported declines in brightness and yellowness of semolina pasta with TG. These authors suggested that protein cross-linking by TG influenced the physical structure of spaghetti, thereby affecting the reflectance properties. Even though faba pasta samples had different colour compared to semolina pasta, this might not affect their potential market acceptance as generally gluten-free pasta (based on corn, rice, etc) also have more yellow and darker intensity colour than semolina pasta.

\subsection{Textural properties}

All faba pasta samples had higher hardness and chewiness values (Table 3) than semolina pasta, as previously reported by Petitot et al. (2010b). Fortification of wheat pasta with legume flours or protein concentrates was reported to cause an increase in firmness of pasta with the increase on protein addition levels (Bahnassey \& Khan, 1986). Faba pasta had statistically similar cohesiveness, resilience, adhesiveness and springiness compared to semolina pasta. Ferm-Faba pasta had the highest hardness, chewiness and resilience values, but the lowest adhesiveness (Table 3). Hardness of pasta samples was significantly inversely correlated with water absorption $(r=-0.89, p<0.01)$ and positively correlated with the protein 
content $(r=0.84, \mathrm{p}<0.05)$. The protein content of spaghetti enriched with lupin protein isolate was also shown to increase the hardness of pasta (Doxastakis et al., 2007). It seemed that the high amount of protein in faba bean pasta samples formed a strong but not elastic protein network. A flexible protein network forms in gluten free faba pasta due to legumins (Sabanis, Makri, \& Doxastakis, 2006) but as its quality is not as good as gluten it interferes with the textural properties. The highest hardness of FermFaba was likely due to the modified starch-protein network of this sample during the fermentation process, which was shown to cause more porous structures and the rupture of starch granules (Coda et al., 2015), inducing the lack of water in the core of pasta (lowest water absorption).

Addition of TG in faba bean flour (Faba-TG) increased the hardness, chewiness, cohesiveness and resilience of pasta and decreased the adhesiveness. TG decreased the adhesiveness of faba and starch pasta to similar levels as semolina pasta. TG has been shown to increase the breaking strength or firmness by cross-linking gluten proteins of pasta made of low-protein semolina (Aalami \& Leelavathi, 2008), commercial semolina pasta (Sissons et al., 2010) and pasta prepared with wheat flour (Kuraishi et al., 2001). In this paper, TG mainly acted on the textural properties of pasta prepared with faba bean flour (Faba-TG), but not significantly in most of the textural parameters of Starch-Faba-TG or Ferm-Faba-TG. This is probably due to the difference in the protein content and matrix of these faba pasta samples, i.e. Starch-Faba has lower amount of protein, which could diminish TG action, and fermentation has been shown to change protein structure making it more porous and releasing free lysine and glutamine (Coda et al., 2015).

\subsection{Starch hydrolysis index (HI)}

The hydrolysis curves of faba bean pastas (Faba, Ferm-Faba and Starch-Faba) (Fig. 3), their $\mathrm{HI}$ and GI (Table 2) were similar to the semolina pasta. These results are in agreement with Petitot \& Micard (2010). Gluten free pasta normally has higher GI than semolina pasta (Foster-Powell, Holt, \& Brand-Miller, 2002), but in the present study, the high amount of protein in faba pasta samples that encapsulates starch granules probably hindered the starch hydrolysis. Addition of TG in faba (Faba-TG) and in fermented faba 
359 (Ferm-Faba-TG) flours decreased their hydrolysis curve, but no effect was observed in Starch-Faba-TG. The $360 \mathrm{HI}$ of Faba-TG pasta was $61 \%$ smaller than Faba pasta. The HI of Ferm-Faba-TG was smaller than Ferm-Faba 361 (35\% reduction), but not significantly different $(p=0.17)$.

The interesting effect of reducing in vitro starch digestibility in pasta by using cross-linking enzymes as

TG has not been reported before. In wheat noodles enriched with soy protein isolate, Gan, Ong, Wong, and

Easa (2009) observed that TG combined with ribose reduced the rates of starch digestion in vitro, but this

effect was not apparent when TG was used individually. TG likely formed several cross-links in faba

proteins, which encapsulated starch in the core of pasta forming a film that decreased the susceptibility of

starch to be digested by enzymes. The encapsulation of starch granules by proteins was previously found to

limit the accessibility of $\alpha$-amylase to starch (Colonna, Barry, Cloarec, Bornet, Gouilloud, \& Galmiche, 1990).

In fact, TG effect could be comparable to the use of very high temperature drying which were shown to

strength the protein network (by increasing of insoluble proteins) resulting in a lower in vitro starch

\subsection{Sensory profiling of pasta}

The cooked pasta samples deviated significantly $(p<0.001)$ from each other regarding all evaluated sensory attributes except stickiness (Fig. 4). Semolina pasta deviated most from the other pasta samples being most elastic, and least hard and chewy, and having least intense flavour. Fermentation clearly increased chewiness, sourness, and flavour and off-flavour intensity. As compared to semolina pasta, use of faba bean flour or starch flour increased hardness and decreased elasticity. In agreement with our results, pasta enriched with faba bean or pea protein also presented higher hardness (Petitot et al., 2010b; Nielsen,

to the higher protein content of Faba pasta ( $350 \mathrm{vs.} 140 \mathrm{~g} / \mathrm{kg}$ ), as observed for durum wheat pasta (Sissons,

382 Egan, \& Gianibelli, 2005). Faba pasta and starch faba bean pasta did not differ significantly from each other $383(p<0.001)$ in any assessed attribute, and they were assessed to have very similar sensory - especially 
textural - characteristics. Fermentation together with TG treatment increased hardness and especially chewiness. The fermented pasta samples were red in colour, indicating a possible Maillard reaction occurrence, hard and chewy in texture, and had sour taste, and intense flavour and off-flavour. Curiel et al. (2014) also reported the presence of an unusual taste in pasta made with wheat flour and lactic acid bacteria, probably due to acidity from sourdough fermentation. The impact of transglutaminase on the textural properties of pasta was not significant, except in increasing the hardness of fermented pasta.

The sensory perception of texture can be statistically explained by instrumentally determined texture parameters. The relation between the perceived texture attributes and instrumental texture of pasta was related by statistical multivariate techniques, by PLS regression (Fig. 5). The instrumental texture attributes explained altogether 95\% (PC1 76\% and PC2 19\%) of the variation between the samples, and perceived sensory attributes $79 \%$ in total (PC1 73\% and PC2 6\%) of the variation. The perceived elasticity was closely related to the instrumental resilience, cohesiveness, springiness and adhesiveness which seemed to measure same property. Thus, based on this observation it might be needless to analyse all those instrumental parameters. In addition, perceived chewiness showed high correlation with instrumental gumminess and chewiness, and was typical to both fermented faba bean pasta and especially to the fermented pasta with the TG treatment. Perceived stickiness could not be well explained by any of the instrumental parameters. Semolina pasta showed very different characteristics, and was therefore located far from the space of the other samples (Fig. 5, arrow in the lower left corner).

\section{Conclusions}

The current trend on the food market and increasing consumer awareness on health and well-being creates a need towards finding new plant based protein ingredients. There is a need to find alternatives for soy protein ingredients due to issues related to genetic modification and allergenicity. Alternative plant protein sources include legumes, cereals and oil crops. Faba beans with their high protein content (25$35 \%)$ which is over twice that of cereals and gluten-free nature, positions them as an alternative plant 
protein ingredient. Another increasing segment with a need of new ingredients and products is the glutenfree market. The current gluten-free products generally have inferior taste, texture and nutritional value compared to their gluten-containing counterparts with high costs. The gluten-free market is in need of protein rich nutritious pasta products.

In this study pasta samples were made using $100 \%$ untreated or processed faba bean flours, i.e. native faba bean flour, faba bean fraction or fermented faba bean flour. The protein levels reached in this study were two-three times higher than regular gluten-free pasta depending on the faba flour or fraction used in the recipe. Compared to semolina, pasta prepared with faba bean flour had lower cooking quality (higher cooking loss and lower water absorption), but cohesiveness, resilience, adhesiveness and springiness were similar to semolina pasta. Starch hydrolysis index (in vitro) of pasta prepared with faba bean was also similar to the reference semolina pasta. Fermentation of faba bean flour with lactic acid bacteria did not improve cooking quality or texture of pasta when compared with unprocessed faba bean pasta. The crosslinking enzyme transglutaminase mainly acted on properties of pasta prepared with faba bean flour, reducing the in vitro starch hydrolysis index and increased some textural parameters (hardness, cohesiveness, chewiness and resilience) likely due to cross-links in the protein network. The sensory texture of the pasta samples was well in line with the instrumental texture. This study showed that faba bean flour and fractions can be used as an ultimate source of high protein gluten-free pasta with textural characteristics and starch hydrolysis index similar to traditional semolina pasta. Further work on the development of other gluten-free faba bean products, such as bread which is known to have a higher GI than pasta would be interesting for understanding the impact of non-gluten protein on structure, texture and starch digestibility.

\section{Acknowledgements}

Arja Viljamaa, Ritva Heinonen and Heidi Eriksson (VTT Technical Research Centre of Finland Ltd) are acknowledged for their excellent assistance in chemical, microscopic and sensory analyses. Fred Stoddard 
434 (University of Helsinki) is acknowledged for providing the faba beans. Funding from the Academy of Finland 435 and VTT, Technical Research Centre of Finland Ltd are gratefully acknowledged. 


\section{References}

AACC (2003). Approved methods of the American association of cereal chemists (10 ${ }^{\text {th }}$ ed.). The Association, St Paul, MN, USA.

AACC International (2013). Approved Methods of Analysis, (11 ${ }^{\text {th }}$ ed.). Method 44-15.02. AACC International, St. Paul, MN, USA.

Aalami, M., \& Leelavathi, K. (2008). Effect of microbial transglutaminase on spaghetti quality. Journal of Food Science, 73, C306-C312.

Abdel-Kader, Z. M. (2000). Enrichment of egyptian 'balady' bread. part 1. baking studies, physical and sensory evaluation of enrichment with decorticated cracked broadbeans flour (vicia faba L.). Nahrung Food, 44, 418-421.

AOAC (1990). Official Methods of Analysis of the Association of Official Analytical Chemist, (15 ${ }^{\text {th }}$ ed.). Association of Official Analytical Chemists, Washington, DC. Method no. 985.29 Total dietary fiber.

Bahnassey, Y., \& Khan, K. (1986). Fortification of spaghetti with edible legumes. II. Rheological, processing, and quality evaluation studies. Cereal Chemistry, 63, 216-219.

Campos-Vega, R., Loarca-Piña, G., \& Oomah, B. D. (2010). Minor components of pulses and their potential impact on human health. Food Research International, 43, 461-482

Chillo, S., Laverse, J., Falcone, P. M., \& Del Nobile, M. A. (2008). Quality of spaghetti in base amaranthus wholemeal flour added with quinoa, broad bean and chick pea. Journal of Food Engineering, 84, 101-107.

Coda, R., Melama, L., Rizzello, C. G., Curiel, J. A., Sibakov, J., Holopainen, U., ... Sozer, N. (2015). Effect of air classification and fermentation by lactobacillus plantarum VTT E-133328 on faba bean (vicia faba L.) flour nutritional properties. International Journal of Food Microbiology, 193, 34-42.

Colonna, P., Barry, J.L., Cloarec, D., Bornet, F., Gouilloud, S., \& Galmiche, J.P. (1990). Enzymic susceptibility of starch from pasta. Journal of Cereal Science, 11, 59-70.

Curiel, J. A., Coda, R., Limitone, A., Katina, K., Raulio, M., Giuliani, G., ... Gobbetti, M. (2014). Manufacture and characterization of pasta made with wheat flour rendered gluten-free using fungal proteases and selected sourdough lactic acid bacteria. Journal of Cereal Science, 59, 79-87.

Doxastakis, G., Papageorgiou, M., Mandalou, D., Irakli, M., Papalamprou, E., D'Agostina, A., ... Arnoldi, A. (2007). Technological properties and non-enzymatic browning of white lupin protein enriched spaghetti. Food Chemistry, 101, 57-64. 
Folk, J. E., \& Finlayson, J. S. (1977). The epsilon-(gamma-glutamyl)lysine crosslink and the catalytic role of transglutaminases. Advances in Protein Chemistry, 31, 1-33.

Foster-Powell, K., Holt, S. H. A., \& Brand-Miller, J. C. (2002). International table of gylcemic index and glycemic load values: 2002. American Journal of Clinical Nutrition, 76, 5-56.

Gan, C.-Y., Ong, W.-H., Wong, L.-M., \& Easa, A. M. (2009). Effects of ribose, microbial transglutaminase and soy protein isolate on physical properties and in-vitro starch digestibility of yellow noodles. LWT - Food Science and Technology, 42, 174-179.

Germaine, K. A., Samman, S., Fryirs, C. G., Griffiths, P. J., Johnson, S. K., \& Quail, K. J. (2008). Comparison of in vitro starch digestibility methods for predicting the glycaemic index of grain foods. Journal of the Science of Food and Agriculture, 88, 652-658.

Giménez, M. A., Drago, S. R., De Greef, D., Gonzalez, R. J., Lobo, M. O., \& Samman, N. C. (2012). Rheological, functional and nutritional properties of wheat/broad bean (vicia faba) flour blends for pasta formulation. Food Chemistry, 134, 200-206.

Giménez, M. A., González, R. J., Wagner, J., Torres, R., Lobo, M. O., \& Samman, N. C. (2013). Effect of extrusion conditions on physicochemical and sensorial properties of corn-broad beans (vicia faba) spaghetti type pasta. Food Chemistry, 136, 538-545.

Granfeldt, Y., Bjorck, I., Drews, A., \& Tovar, J. (1992). An in vitro procedure based on chewing to predict metabolic response to starch in cereal and legume products. European Journal of Clinical Nutrition, 46(9), 649-660.

Guillon, F., \& Champ, M.M.-J. (2002). Carbohydrate fractions of legumes: uses in human nutrition and potential for health. British Journal of Nutrition, 88(SUPPL. 3), S293-S306.

Gunawardena, C., Zijlstra, R., \& Beltranena, E. (2010). Characterization of the nutritional value of airclassified protein and starch fractions of field pea and zero-tannin faba bean in grower pigs. Journal of Animal Science, 88, 660-670.

Jamalian, J. (1999). Removal of favism-inducing factors vicine and convicine and the associated effects on the protein content and digestibility of faba beans (Vicia faba L). Journal of the Science of Food and Agriculture, 79, 1909-1914.

Jezierny, D., Mosenthin, R., \& Bauer, E. (2010). The use of grain legumes as a protein source in pig nutrition: A review. Animal Feed Science and Technology, 157, 111-128. 
ISO 6658:2005. Sensory analysis -- Methodology -- General guidance. 20 p.

ISO 8589:2007. Sensory analysis -- General guidance for the design of test rooms. $16 \mathrm{p}$.

Kim, Y., Kee, J. I., Lee, S., \& Yoo, S.-H. (2014). Quality improvement of rice noodle restructured with rice protein isolate and transglutaminase. Food Chemistry, 145, 409-416.

Kuraishi, C., Yamazaki, K., \& Susa, Y. (2001). Transglutaminase: Its utilization in the food industry. Food Reviews International, 17, 221-246.

Lawless, H. T., \& Heymann, H. (2010). Sensory evaluation of food principles and practises, descriptive analysis. (2nd ed.) Gaithersburg: Chapman \& Hall/Aspen Publishers, Inc. (pp. 378-441).

Luo, Y.-W., \& Xie, W.-H. (2013). Effect of different processing methods on certain antinutritional factors and protein digestibility in green and white faba bean (vicia faba L.). CYTA - Journal of Food, 11, 43-49.

Marti, A., \& Pagani, M. A. (2013). What can play the role of gluten in gluten free pasta? Trends in Food Science and Technology, 31, 63-71.

Marti, A., Seetharaman, K., \& Pagani, M. A. (2010). Rice-based pasta: A comparison between conventional pasta-making and extrusion-cooking. Journal of Cereal Science, 52(3), 404-409.

Nielsen, M.A., Sumner, A.K., \& Whalley, L.L. (1980). Fortification of pasta with pea flour and air-classified pea protein concentrate. Cereal Chemistry, 57, 203-206.

Petitot, M., Barron, C., Morel, M.-H., \& Micard, V. (2010a). Impact of legume flour addition on pasta structure: Consequences on its in vitro starch digestibility. Food Biophysics, 5, 284-299.

Petitot, M., Boyer, L., Minier, C., \& Micard, V. (2010b). Fortification of pasta with split pea and faba bean flours: Pasta processing and quality evaluation. Food Research International, 43, 634-641.

Petitot, M., \& Micard, V. (2010). Legume-fortified pasta. Impact of drying and precooking treatments on pasta structure and inherent in vitro starch digestibility. Food Biophysics, 5, 309-320.

Rababah, T.M. (2006). Effect of chickpea, broad bean, or isolated soy protein additions on the physicochemical and sensory properties of biscuits. Journal of Food Science, 71, S438-S442.

Sabanis, D., Makri, E., \& Doxastakis, G. (2006). Effect of durum flour enrichment with chickpea flour on the characteristics of dough and lasagne. Journal of the Science of Food and Agriculture, 86(12), 1938-1944. 
Sozer, N., Dalgiç, A. C., \& Kaya, A. (2007). Thermal, textural and cooking properties of spaghetti enriched with resistant starch. Journal of Food Engineering, 81, 476-484.

Sissons, M., Aravind, N., \& Fellows, C. M. (2010). Quality of fiber-enriched spaghetti containing microbial transglutaminase. Cereal Chemistry, 87, 57-64.

Sissons, M. J., Egan, N. E., \& Gianibelli, M. C. (2005). New insights into the role of gluten on durum pasta quality using reconstitution method. Cereal Chemistry, 82, 601-608.

Tovar, J., Björck, I. M., \& Asp, N.-G. (1990). Analytical and nutritional implications of limited enzymic availability of starch in cooked red kidney beans. Journal of Agricultural and Food Chemistry, 38, 488-493.

Yalcin, S., \& Basman, A. (2008). Quality characteristics of corn noodles containing gelatinized starch, transglutaminase and gum. Journal of Food Quality, 31, 465-479. 


\section{FIGURE CAPTIONS}

Figure 1. Brightfield images of pasta samples stained with Light Green and Lugol's iodine (protein appears light green and the amylose component of starch blue and amylopectin brown). A - D: Uncooked pasta samples with panels showing an image with higher magnification taken from the centre of the sample. E K: Micrographs taken on the edge of pasta samples cooked to the optimum time. A and E: Faba; B and F: Starch-Faba; C and G: Ferm-Faba; D and H: Semolina; I: Faba-TG; J: Starch-Faba-TG; K: Ferm-Faba-TG).

Figure 2. Brightfield images of pasta samples cooked to the optimum time stained with Light Green and Lugol's iodine (protein appears light green and the amylose component of starch blue and amylopectin brown). Micrographs represent a location in the depth of $1 / 4$ of the spaghetti diameter from the surface. A: Faba; B: Faba-TG; C: Starch-Faba; D: Starch-Faba-TG; E: Ferm-Faba; F: Ferm-Faba-TG; G: Semolina

Figure 3. Starch hydrolysis curves of pasta made with faba bean flour (black circle), starch fraction of faba bean (black triangle) and fermented faba bean flour (black square). The curves of samples prepared with transglutaminase (TG) enzyme are represented by dotted lines and correspondent open symbols, i.e. open circle, triangle and square for Faba-TG, Starch-Faba-TG and Ferm-Faba-TG, respectively. Semolina pasta curve is represented by a grey diamond. The vertical axis reports the mg of maltose per $1 \mathrm{~g}$ of starch, and the horizontal axis displays time (min).

Figure 4. Sensory evaluation ( $n=2 \times 10)$ of cooked pasta made with faba bean flour (Faba - blue square), starch fraction of faba bean (Starch-Faba - orange circle), fermented faba bean flour (Ferm-Faba- violet triangle). The samples prepared with transglutaminase (TG) enzyme are represented by dotted lines and correspondent open symbols, i.e. open green square, open brown circle and open red triangle for Faba-TG, Starch-Faba-TG and Ferm-Faba-TG, respectively. Pasta prepared with semolina (blue cross) was used as a reference.

Figure 5. PLS regression plot of sensory and instrumental texture data of pasta made with faba bean flour (Faba), starch fraction of faba bean (Starch-Faba), and fermented faba bean flour (Ferm-Faba) with or 
without addition of transglutaminase (TG) enzyme. T- indicate instrumental and S- indicate sensory texture parameters. The arrow indicates that semolina sample was located far from the space of the other samples.

Comment citer ce document : 
TABLES

Table 1. Chemical composition of pasta made with faba bean flour (Faba), starch fraction of faba bean (Starch-Faba), and fermented faba bean flour (Ferm-Faba) with or without addition of transglutaminase (TG) enzyme.

\begin{tabular}{lccccccc}
\hline & Protein & Starch & Total fibre & Fat & Moisture & Ash & RS \\
\hline Faba & $35.4 \pm 0.1$ & $43.5 \pm 0.3$ & $7.2 \pm 0.3$ & $1.5 \pm 0.0$ & 8.2 & 3.8 & $1.5 \pm 0.0$ \\
Faba-TG & $35.1 \pm 0.1$ & $44.5 \pm 0.4$ & $7.2 \pm 0.3$ & $1.5 \pm 0.0$ & 8.5 & 3.7 & $2.0 \pm 0.1$ \\
Starch-Faba & $23.7 \pm 0.1$ & $58.7 \pm 0.1$ & $4.6 \pm 0.1$ & $0.8 \pm 0.0$ & 8.6 & 2.7 & $1.8 \pm 0.1$ \\
Starch-Faba-TG & $23.3 \pm 0.1$ & $58.7 \pm 0.0$ & $4.6 \pm 0.1$ & $0.8 \pm 0.0$ & 8.4 & 2.6 & $2.7 \pm 0.0$ \\
Ferm-Faba & $35.3 \pm 0.2$ & $43.4 \pm 0.3$ & $6.6 \pm 0.4$ & $0.9 \pm 0.0$ & 7.7 & 4.4 & $1.2 \pm 0.0$ \\
Ferm-Faba TG & $35.1 \pm 0.1$ & $43.3 \pm 0.2$ & $6.6 \pm 0.4$ & $0.9 \pm 0.0$ & 7.6 & 4.4 & $1.1 \pm 0.1$ \\
Semolina & $14.2 \pm 0.1$ & $73.5 \pm 0.3$ & 2.4 & 2.3 & 8.7 & 1.0 & $0.5 \pm 0.1$ \\
\hline
\end{tabular}

Protein, starch, total fibre, fat, ash and resistant starch (RS) contents are expressed in $g / 100 \mathrm{~g}(\mathrm{dm})(\mathrm{n}=2)$. 
Table 2. Cooking properties (optimal cooking time, cooking loss and water absorption), diameter (uncooked, hydrated in glutaraldehyde and cooked) and colour of pasta made with faba bean flour (Faba), starch fraction of faba bean (Starch-Faba), and fermented faba bean flour (Ferm-Faba) with or without addition of transglutaminase (TG) enzyme.

\begin{tabular}{|c|c|c|c|c|c|c|c|c|c|c|c|}
\hline & \multirow{3}{*}{$\begin{array}{l}\mathrm{OCT}^{+} \\
(\mathrm{min}) \\
(\mathrm{n}=2)\end{array}$} & \multirow{3}{*}{$\begin{array}{c}\text { Water } \\
\text { absorption (\%) } \\
(n=3)\end{array}$} & \multirow{3}{*}{$\begin{array}{c}\text { Cooking loss } \\
\begin{array}{c}(\%, \mathrm{db}) \\
(\mathrm{n}=3)\end{array}\end{array}$} & \multicolumn{3}{|c|}{ Diameter $(\mathrm{mm})(\mathrm{n}=48)$} & \multicolumn{3}{|c|}{ Colour of dried pasta $(n=9)$} & \multirow[t]{3}{*}{$\mathrm{HI}^{\ddagger}(\mathrm{n}=3)$} & \multirow[t]{3}{*}{$\mathrm{Gl}^{\text {t+ }}$} \\
\hline & & & & uncooked & hydrated & cooked & $L^{*}$ & a* & $b^{*}$ & & \\
\hline & & & & & & & & & & & \\
\hline Faba & 6.5 & $162 \pm 5^{b}$ & $10.8 \pm 0.1^{\mathrm{ab}}$ & $1.54 \pm 0.02^{a}$ & $2.16 \pm 0.04^{d}$ & $2.60 \pm 0.04^{d}$ & $52.4 \pm 1.4^{b}$ & $4.2 \pm 0.3^{b}$ & $20.3 \pm 0.8^{b c}$ & $50.7 \pm 4.8^{c}$ & $51.9 \pm 4.1^{c}$ \\
\hline Faba-TG & 6.5 & $167 \pm 9^{b}$ & $11.3 \pm 0.7^{\mathrm{a}}$ & $1.54 \pm 0.02^{\mathrm{ab}}$ & $2.15 \pm 0.04^{d}$ & $2.53 \pm 0.05^{b}$ & $48.7 \pm 1.6^{c}$ & $3.9 \pm 0.2 b^{c}$ & $17.7 \pm 1.0^{d}$ & $19.7 \pm 3.5^{\mathrm{a}}$ & $25.1 \pm 3.0^{\mathrm{a}}$ \\
\hline Starch-Faba & 9 & $195 \pm 1^{\mathrm{a}}$ & $11.8 \pm 0.3^{\mathrm{a}}$ & $1.56 \pm 0.02^{\mathrm{cd}}$ & $2.14 \pm 0.04^{d}$ & $2.58 \pm 0.04^{c d}$ & $52.6 \pm 1.1^{\mathrm{b}}$ & $3.5 \pm 0.4^{c}$ & $18.9 \pm 1.2^{c d}$ & $49.2 \pm 9.3^{b c}$ & $50.6 \pm 8.0^{\mathrm{bc}}$ \\
\hline Starch-Faba-TG & 9 & $195 \pm 2^{a}$ & $11.7 \pm 0.2^{a}$ & $1.57 \pm 0.03^{d}$ & $2.19 \pm 0.04^{\mathrm{e}}$ & $2.63 \pm 0.05^{\mathrm{e}}$ & $54.0 \pm 1.0^{b}$ & $3.8 \pm 0.3 b^{c}$ & $20.7 \pm 0.6^{b}$ & $40.0 \pm 1.9^{a b c}$ & $42.7 \pm 1.6^{\mathrm{abc}}$ \\
\hline Ferm-Faba & 6 & $132 \pm 5^{c}$ & $11.5 \pm 0.3^{\mathrm{a}}$ & $1.55 \pm 0.02^{\mathrm{abc}}$ & $2.04 \pm 0.03^{c}$ & $2.37 \pm 0.03^{a}$ & $42.6 \pm 1.1^{d}$ & $11.0 \pm 0.8^{\mathrm{a}}$ & $12.9 \pm 0.9^{\mathrm{e}}$ & $46.3 \pm 5.4^{b c}$ & $48.1 \pm 4.6^{b c}$ \\
\hline Ferm-Faba-TG & 6 & $132 \pm 6^{c}$ & $10.3 \pm 0.4^{b}$ & $1.54 \pm 0.03^{\mathrm{abc}}$ & $1.97 \pm 0.03^{b}$ & $2.37 \pm 0.03^{a}$ & $42.0 \pm 0.6^{d}$ & $11.0 \pm 0.4^{\mathrm{a}}$ & $12.5 \pm 0.5^{\mathrm{e}}$ & $30.1 \pm 3.5^{\mathrm{ab}}$ & $34.2 \pm 3.0^{\mathrm{ab}}$ \\
\hline Semolina & 10 & $193 \pm 4^{\mathrm{a}}$ & $6.4 \pm 0.2^{c}$ & $1.56 \pm 0.02^{\mathrm{bcd}}$ & $1.85 \pm 0.03^{a}$ & $2.56 \pm 0.04^{c}$ & $58.3 \pm 1.2^{\mathrm{a}}$ & $1.6 \pm 0.2^{d}$ & $22.5 \pm 1.3^{\mathrm{a}}$ & $45.6 \pm 14.5^{b c}$ & $47.5 \pm 12^{\mathrm{bc}}$ \\
\hline
\end{tabular}

${ }^{\dagger}$ Optimal cooking time; ${ }^{\ddagger}$ Starch hydrolysis index; ${ }^{+\dagger}$ Predicted glycemic index 
Table 3. Textural properties of pasta made with faba bean flour (Faba), starch fraction of faba bean (Starch-Faba), and fermented faba bean flour (FermFaba) with or without addition of transglutaminase (TG) enzyme $(n=10)$.

\begin{tabular}{lcccccc}
\hline & Hardness (N) & Chewiness (N) & Adhesiveness (N.s) & Cohesiveness & Resilience & Springiness \\
\hline Faba & $172 \pm 10^{\mathrm{c}}$ & $97 \pm 11^{\mathrm{c}}$ & $1.21 \pm 0.18^{\mathrm{c}}$ & $0.67 \pm 0.04^{\mathrm{c}}$ & $0.41 \pm 0.04^{\mathrm{e}}$ & $0.84 \pm 0.03^{\mathrm{a}}$ \\
Faba-TG & $199 \pm 8^{\mathrm{b}}$ & $128 \pm 10^{\mathrm{b}}$ & $0.93 \pm 0.28^{\mathrm{b}}$ & $0.74 \pm 0.02^{\mathrm{b}}$ & $0.50 \pm 0.02^{\mathrm{bc}}$ & $0.87 \pm 0.03^{\mathrm{a}}$ \\
Starch-Faba & $161 \pm 6^{\mathrm{c}}$ & $102 \pm 10^{\mathrm{c}}$ & $1.53 \pm 0.22^{\mathrm{d}}$ & $0.74 \pm 0.01^{\mathrm{b}}$ & $0.44 \pm 0.01^{\mathrm{de}}$ & $0.85 \pm 0.06^{\mathrm{a}}$ \\
Starch-Faba-TG & $171 \pm 5^{\mathrm{c}}$ & $112 \pm 6^{\mathrm{bc}}$ & $1.11 \pm 0.16^{\mathrm{bc}}$ & $0.75 \pm 0.01^{\mathrm{b}}$ & $0.47 \pm 0.01^{\mathrm{cd}}$ & $0.88 \pm 0.02^{\mathrm{a}}$ \\
Ferm-Faba & $238 \pm 11^{\mathrm{a}}$ & $153 \pm 14^{\mathrm{a}}$ & $0.47 \pm 0.08^{\mathrm{a}}$ & $0.74 \pm 0.05^{\mathrm{b}}$ & $0.54 \pm 0.06^{\mathrm{ab}}$ & $0.86 \pm 0.03^{\mathrm{a}}$ \\
Ferm-Faba-TG & $243 \pm 15^{\mathrm{a}}$ & $170 \pm 20^{\mathrm{a}}$ & $0.58 \pm 0.05^{\mathrm{a}}$ & $0.78 \pm 0.02^{\mathrm{a}}$ & $0.57 \pm 0.03^{\mathrm{a}}$ & $0.89 \pm 0.03^{\mathrm{a}}$ \\
Semolina & $116 \pm 8^{\mathrm{d}}$ & $70 \pm 4^{\mathrm{d}}$ & $1.07 \pm 0.26^{\mathrm{bc}}$ & $0.69 \pm 0.02^{\mathrm{c}}$ & $0.42 \pm 0.02^{\mathrm{e}}$ & $0.88 \pm 0.02^{\mathrm{a}}$ \\
\hline
\end{tabular}




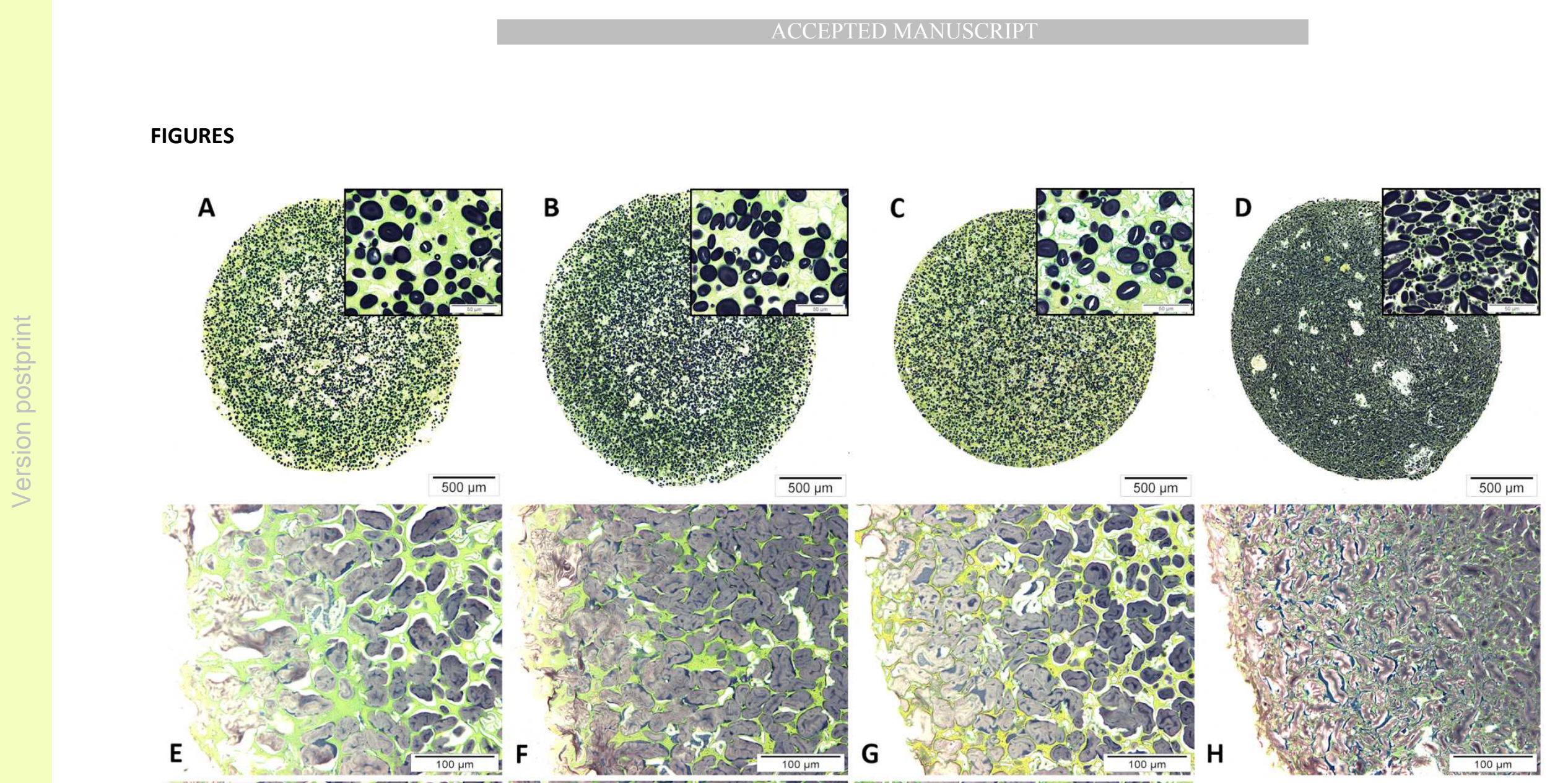

A

$500 \mu \mathrm{m}$ $\overline{500 \mu \mathrm{m}}$

E 5 . 5 ?

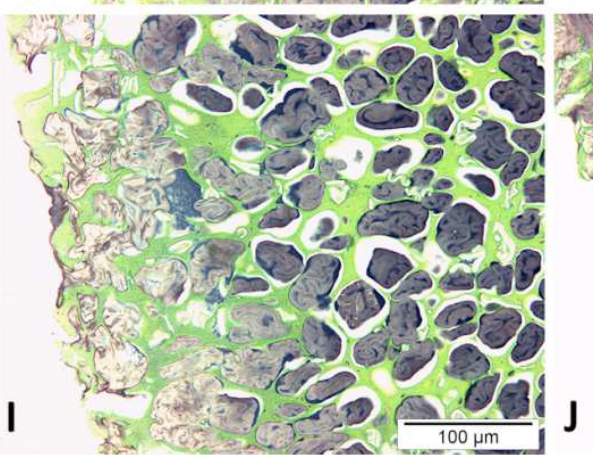

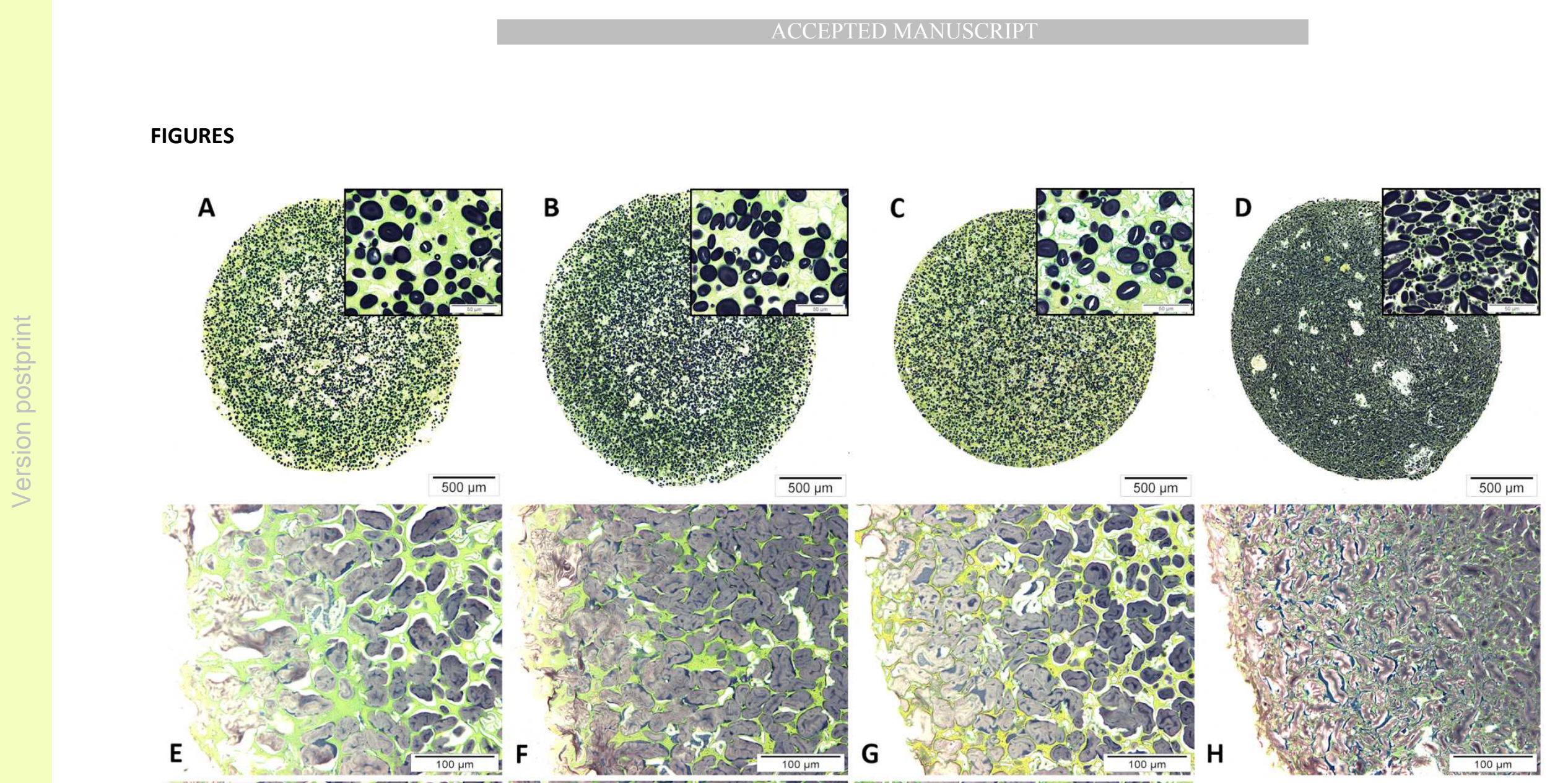

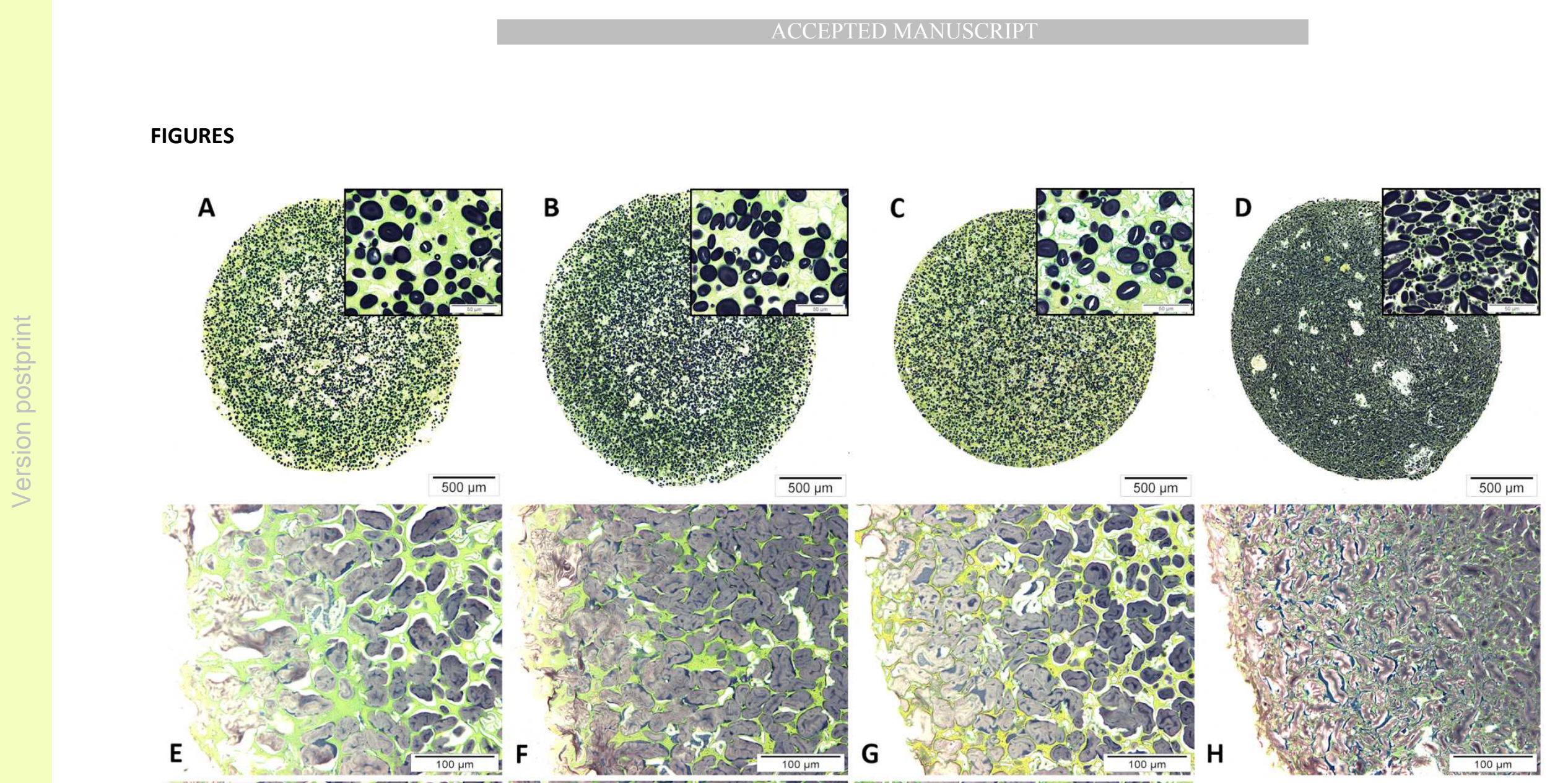
$\overline{500 \mu \mathrm{m}}$
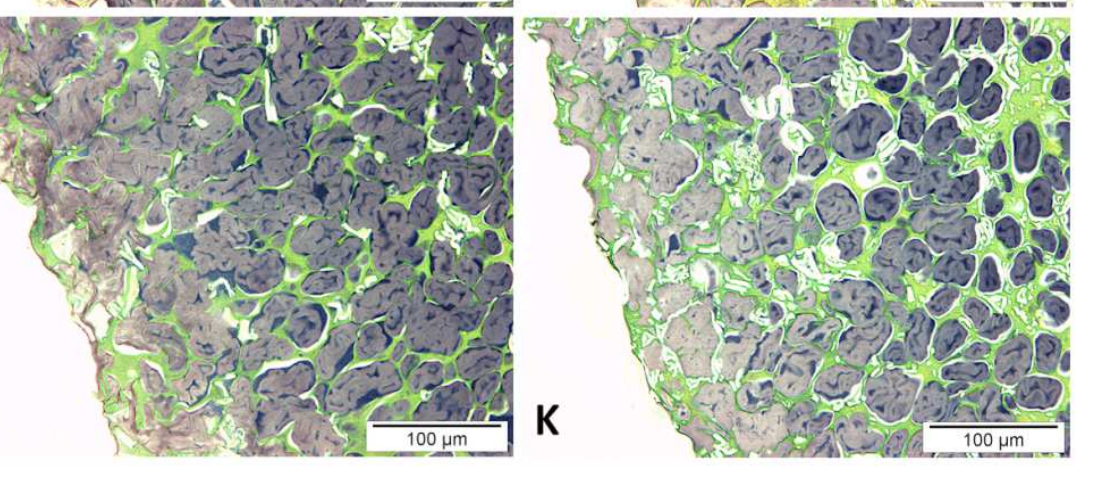

Figure 1

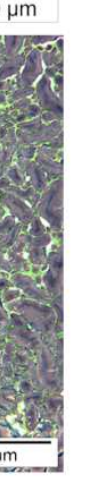

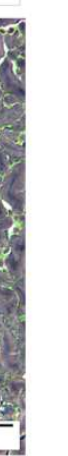
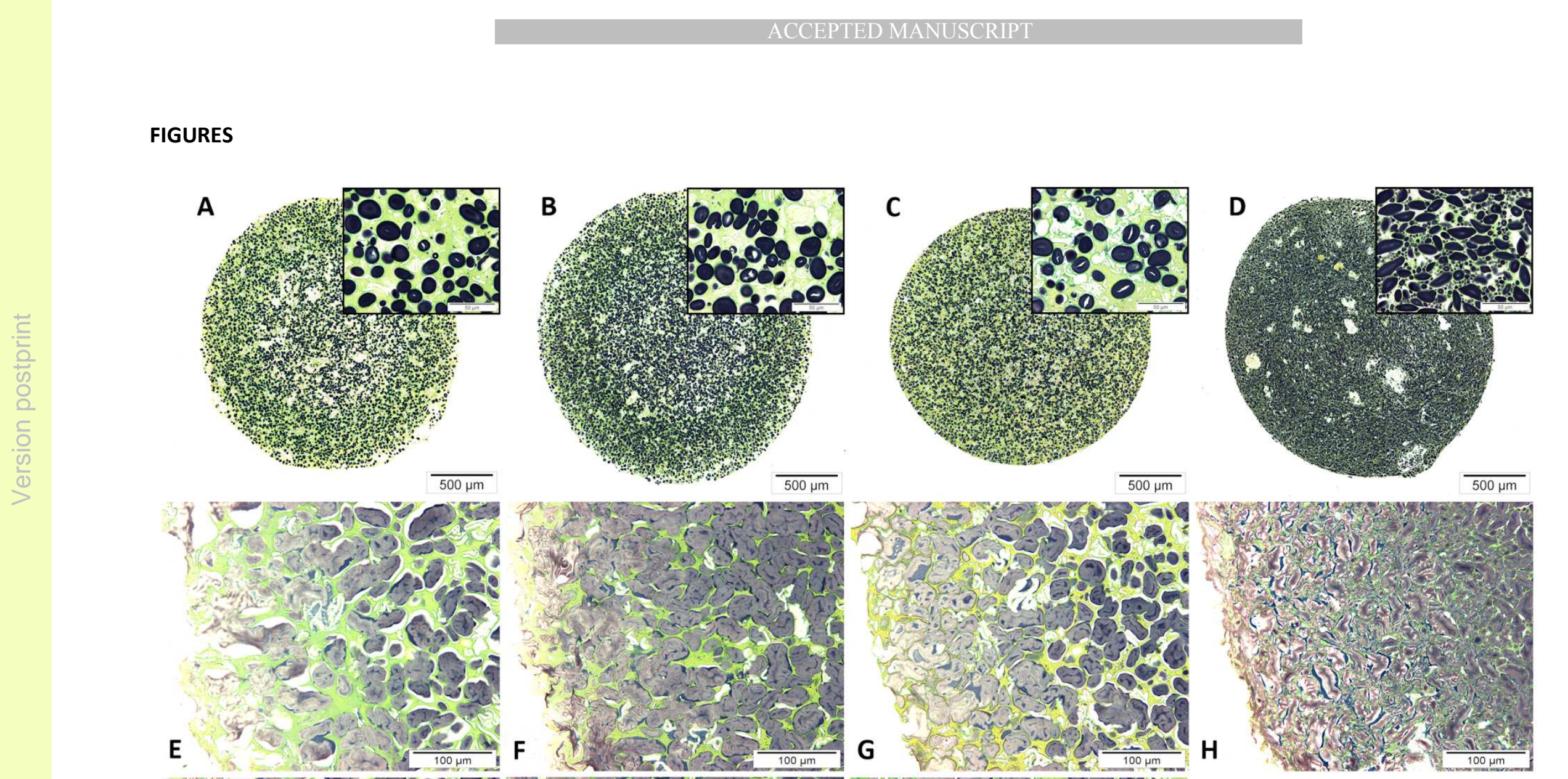

Comment citer ce document : 

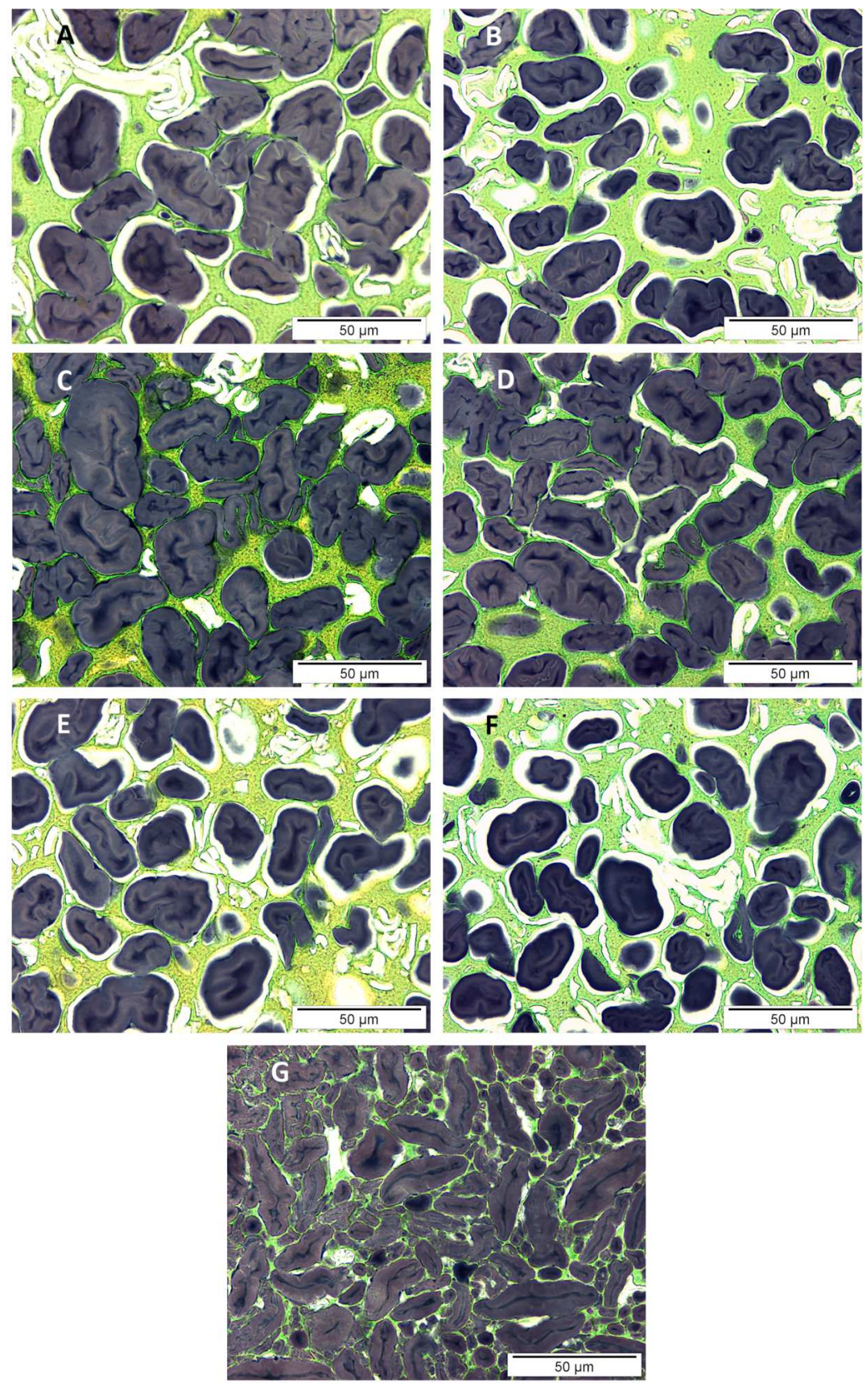

Figure 2 


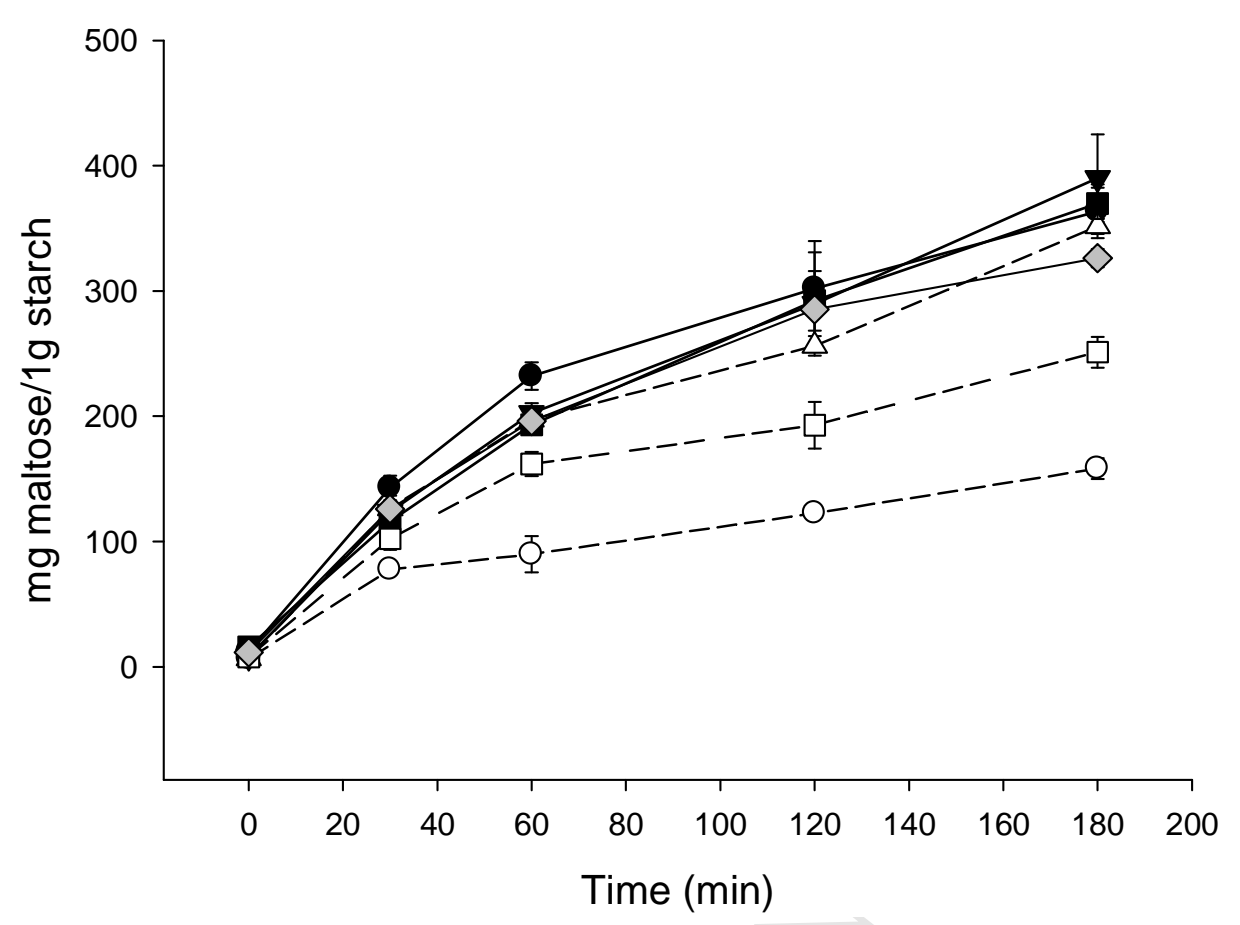

Figure 3

Comment citer ce document 


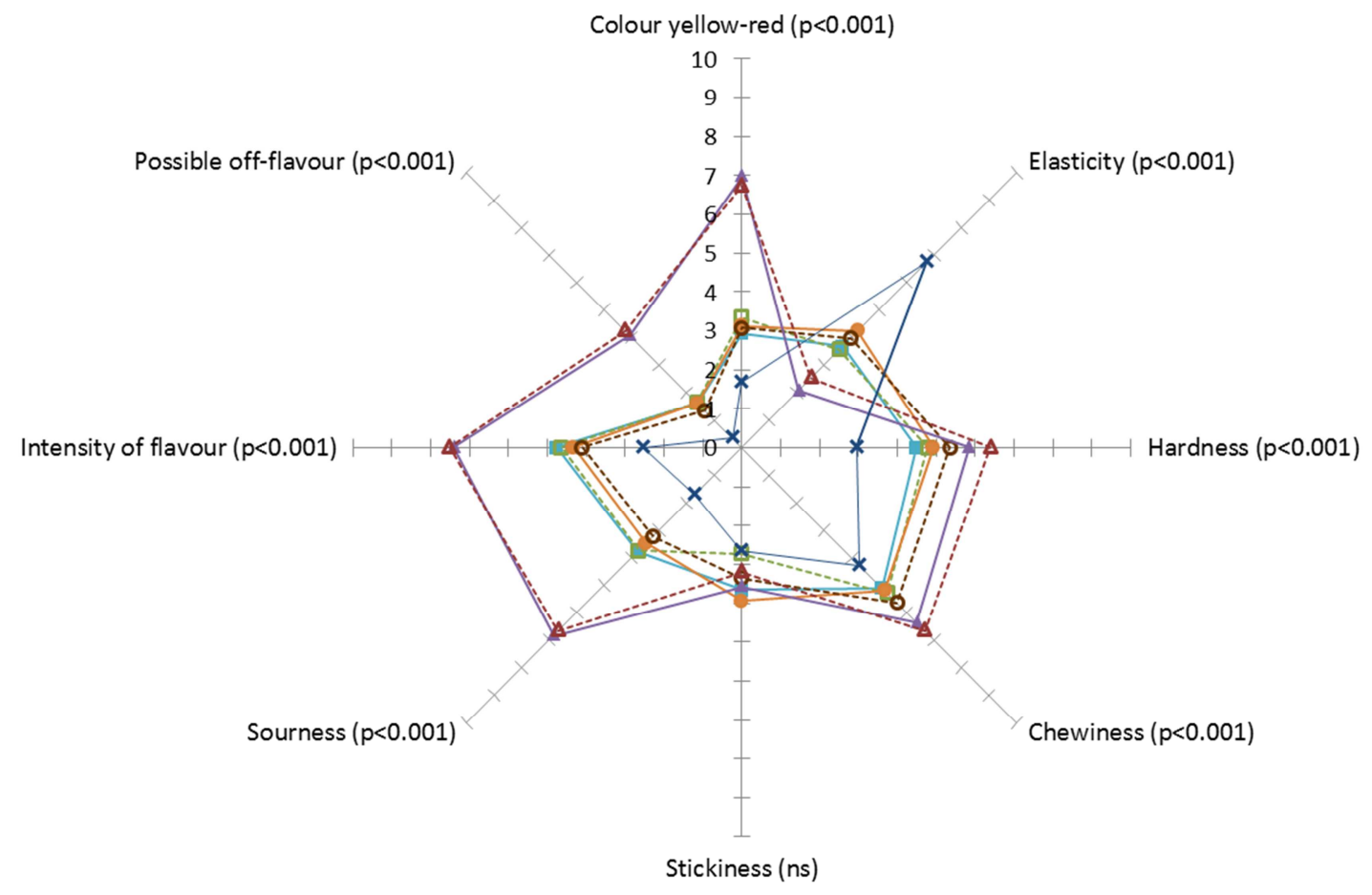

Figure 4

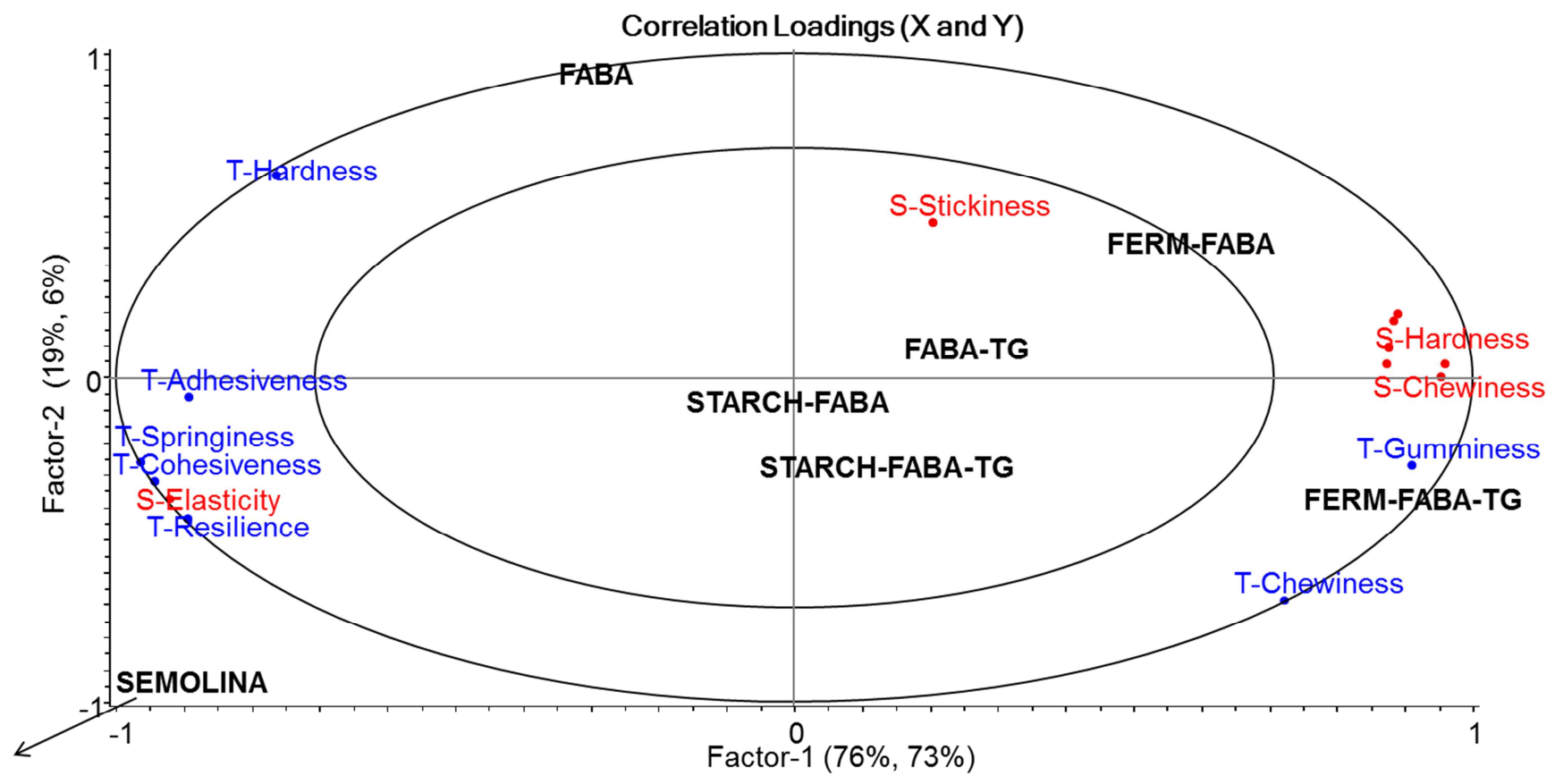

Figure 5 
Highlights

- Gluten-free pasta made from bioprocessed faba bean flour and its fractions

- Faba bean pasta had lower cooking quality than semolina pasta, but similar texture

- In vitro starch digestibility of faba bean pasta was similar to the semolina pasta

- Cross-linking enzyme further decreased the in vitro starch digestibility 